\title{
Synapsis Expression Increased By Mozart's Music Stimulation Compared With Indonesian Pop And Religious Music
}

\author{
Ukhti Mukminah Ilmi Amila', Hermanto' ${ }^{2}$ Widjiati $^{3}$ \\ ${ }^{1}$ Ilmu Kesehatan Reproduksi Fakultas Kedokteran Universitas Airlangga, \\ 2Departemen Obstetri dan Ginekologi Fakultas Kedokteran Universitas Airlangga \\ - RSUD Dr. Soetomo Surabaya \\ ${ }^{3}$ Departemen Anatomi Veterenier Fakultas Kedokteran Hewan Universitas \\ Airlangga
}

Email : ukhti.amila@ymail.com

Receive : Jan $13^{\text {th }}$ 2020. Revised : Mey $9^{\text {th }}$ 2020. Published: Jun $27^{\text {th }} 2020$

DOI: https://doi.org/10.22219/sm.Vol16.SMUMM1.10784

\begin{abstract}
Classical music stimulation is a proven method that affect intelligence as well as brain function. Mozart's classical music is classical music that could stimulate the growth of synaptic networks. To analyze the difference of synapsin expression of the brain of Rattus norvegicus offspring on Mozart's, pop, religious and without music stimulation during pregnancy. Experimental. Treatments were subjected to Rattus norvegicusas a subject organism, initiated on the $10^{\text {th }}$ day of pregnancy, in 1 hour duration in a soundproof chamber, intensity of 65 $\mathrm{dB}$. On the $19^{\text {th }}$ day of pregnancy the subjects were sacrificed and three offsprings were chosen. The head of the chosen Rattus norvegicusoffsprings were decapitated and the brain subsequently sectioned to calculate synapsin expression by immunohistochemistry method with 400 magnification strength microscope on the 5 field of view. Significant difference of synapsin expression of the brain of Rattus norvegicus offspring was observed between Mozart's and control group. Significant differences of synapsin expressions were observed in the cerebellum of the newly born Rattus novergicus between Mozart and pop music groups ( $p=0,007)$, Mozart and religious music groups $(\mathrm{p}=0,008)$, Mozart and without music groups $(\mathrm{p}=0,004)$.Synapsin expression of Rattus norvegicus brain offsprings were higher in Mozart music stimulation compared with pop and religious music stimulation
\end{abstract}

Keywords : Mozart, pop, religious, Synapsin.

Copyright (C) 2020, First Author et al This is an open access article under the CC-BY-SA license

\section{INTRODUCTION}

Health care in fetal intelligence is crucial in the process of developing a new generation with quality. Intelligence is a determining factor of the quality of the generation. Based on the Human Development Index (HDI) data, in 2018 Indonesia was standing in the 133 $3^{\text {rd }}$ position of 189 countries. One of HDI indicator including education, thus effort to improve human resources with intelligence needs a positive correlation between human well being and a good quality education (UNDP, 2018)

Intelligence could be interpreted as a biopsychosocial potential that may be employed in the culture of problem solving or producing a novel proposition, related to innervation or in this 
instance, the brain. In the central nervous system, stimulation and information are processed through synapsin or interneuron connection. Higher quantity of individuals synapsin and dentrites lead to faster information process by the central nervous system (Hermanto, 2004).

Synapsin is a connection that controls interneuron communication. Information that come through the neuron caused by the pra-synapsis will release neurotransmitter through synapsis gaps that serve to deliver impulses from pre-synapsin to post-synapsin (Gabriel, 1998)

In the study of intrauterine fetal intelligence stimulation that subjected to the rats indicated a higher brain cells proliferation in the music exposed rat fetuses compared to the controls. Classical music exposure is stated induce higher proliferation compared with "gamelan" (Indonesian traditional music) and dangdut (Indonesian typical music) (Hermanto,2002).

This study is the continuation of a series of previous study of increasing fetal intelligence aiming to determine the effect of Mozart's pop and religious music during pregnancy to the cerebrum and cerebellum synapsin expression of Rattus norvegicus offspring.

\section{METHODS}

This study was an experimental analytical study which employs post test only control group design. Rattus norvegicuswas employed as a subject organism that subjected to Mozart music stimulation to replace pregnant women for the study. The study was conducted at Veterinary Medicine Faculty of Airlangga University, Surabaya between June and October 2019. Samples were female Sprague Dowley strain of Rattus norvegicus aged $2-3$ months with initial weight of $120-130$ grams, pregnant. Inclusion criteria including has no history of receiving any treatment or subjected to previous study, and nulliparous.

Subjects were put into adaptation process for 7 days or 1 week in a cage. Superovulation subsequently induced by 10 IU Hormone Pregnant Mare Serum Gonadotropin (PMSG) injection, proceeded with $10 \mathrm{IU}$ hCG injection 48 hours later, then copulated by monomatting technique. When copulatory plug (vaginal plug) that covers the cervix to the vulva present, impregnation was considered succeed. Group were randomized into 4 treatment groups. Group I was exposed with Mozart's music, group II was exposed with Pop music, group III was exposed with religious music, and group IV wwas not exposed to any music. Music exposure was initiated at the $10^{\text {th }}$ day of pregnancy for 9 days, 60 minutes duration in a soundproof chamber. Pregnant rats were sacrificed at the $19^{\text {th }}$ day of pregnancy, anesthetized by chloroform by entering the rats into a glass jar filled with chloroform-containing cotton. Samples (Rattus norvegicus offsprings) were taken immediately, 3 live offspring with the heaviest, moderate, and smallest body weight were sacrificed, anesthetized by entering the subjects (Rattus norvegicus) into a glass jar filled with chloroform-containing contton, sectioned to take the brain for immunihistochemistry procedure to observe synapsin expression. The remaining tissues were buried. 
Synapsin expression calculation was performed to each sample. Subsequently compared between groups by statistical analysisi. Neither the researcher, mentor nor the examiner aware of the results until all the results of samples examined in 5 field of view and 400 magnification strength available. Statistical analysis then performed by Kruskal-Wallis test, proceeded with Mann Whitney difference test.

\section{RESULTS AND DISCUSSION}

This study was conducted to compare the synapsin expression between Mozart, pop and religious music exposure. All the treatments were initiated on the $10^{\text {th }}$ day of pregnancy. The objective of this study was to determine the correlation of Mozart's, pop, religious and without music exposure to the cerebrum and cerebellum of Rattus norvegicus offspring synapsin expression. This study, later on may be employed to verify brain cellular alteration due to the exposure of those certain music.

This study observed the highest mean synapses expression in Mozart's music group, consistent with the proposed initial hypothesis. Mozart's music could produce the highest synapses expression due to its major and minor tones composition that induce relaxation which affect synapstogenesis.

Table 1. Mean and standar deviation of the brainsynapsin expression of Rattus norvegicus offsprings of Mozart's, pop, and religious music exposed parents

\begin{tabular}{ccc}
\hline Group & $\mathrm{n}$ & Mean $\pm S D$ \\
\hline Mozart's & 7 & $3,28 \pm 0,71$ \\
Pop & 7 & $2,28 \pm 0,58$ \\
Religious & 7 & $2,31 \pm 0,69$ \\
\hline
\end{tabular}

Table1. showed the highest synapsin expression of the offsprings brain in the Mozart's music group. This is due to Mozart's music tone and rhythm heard by the fetal ear enter the canalis auditorious, subsequently stimulating raphe dorsalis nucleous to facilitate serotonin release. This serotonin also suppress apoptosis whch influences the process of synapstogenesis (Rees,2001). Syanpsin expression may be affected by different frequencies in each music. This study observed significant synapsin expression difference between Mozart's music exposed group compared with without music exposure group. The result is consistent with previous study conducted by Hermanto in 2012 that indicates Mozart's music has the prime combination of frequency, intensity, and vibration compatible with brain waves. Sound that reach the ear could be delivered to the brain, because the ear act as an energy generator of the brain which will affect the brain itself as well 
as the whole body. The study conducted by Hermanto (2012) signify that Mozart's music produce $60-80$ beats per minute (bpm) which is in accordance with the mother's heart rhythm, therefore Mozart's music easily appropriate for fetal brain. Furthermore, Mozart's music has a minimum amount of minor tones, major tones has the ability to deliver happiness stimulation throughout the brain that leads to increased endorphine hormone release.

Another study also suggested that a one hour duration of $65 \mathrm{~dB}$ music exposure strogly correlated with the cerebellum expression synapsin and BDNF. Music stimulation could increase neuron complexity through synapstogenesis process, a faster sinapses formation leads to increased brain information processes (Ji et al., 2005).

The mean of cerebrum and cerebellum synapsisn expression of Mozart's music exposed group was higher compared with pop, religious and without music exposure groups. Music served as an information delivery means and may be used as a stimulation tool. Potter (2005) stated that a fetus that grows in a rich stimulation environment may enable a higher quantity of synapses formation. Mozart's music exposure is superior compared to other music stimulation, since Mozart's music has an intensity, frequnecy and melody coherence appropriate with brain frequency (Hermanto, 2012)

During pregnancy, fetus develop its complete hearing function at 20 weeks gestation, therefore music stimulation performed at the right time as well as mother-fetus communication could increase fetus brain development (Parncutt, 2006). Previous study by Syania (2019) indicated that significant influence on the number neuron in the Mozart's msic group compared with Jazz, blues, and rock music. This result is consistent with the current analysis result that showed higher synapsin expression in the Mozart's music group compared with pop, religious, and without music exposure groups.

\section{CONCLUSION}

Synapsin expression of Rattus norvegicus brain offsprings were higher in Mozart music stimulation compared with pop and religious music stimulation. Further study on the more spesific parts of the brain is necessary.

\section{REFERENCES}

Gabriel JF. 1988. Fisika Kedokteran. Penerbit Buku Kedokteran EGC, Jakarta. Hal: 65-98

Hermanto TJ, Estoepangesti ATS dan Widjiati. 2002. The influence of musical exposure to pregnant (Rattus Novergicus) Rat to the amount of neonatal rat brain cells. Abstract of the 3rd Scientific meeting on Fetomaternal Medicine and AOFOG Accredited Ultrasound Workshop. 2002: 31.

. 2004. Smart babies through Prenatal University Mission Impossible. Majalah Obstetri dan Ginekologi Indonesia, 28(1):14. 
. 2012. Bersujud dalam Rahim 2, Mencerdaskan Janin sejak dalam Rahim dengan KombinasiStimulasi 11 - 14 Musik Mozart dan Nutrisi. Global Persada Press. Surabaya

Ji, Y., Pang, P.T., Feng L., and Lu B. 2005. Cyclic AMP controls BDNF-induced TrkB phosphorylation dan dendritic spine formation in mature hippocampal neurons. Nat Neurosci;;8:164-172.

Parncutt R, 2006. Prenatal Development. Mc Pher chap 01: 1-22

Rees, S., and D. Walker. 2001. Nervous and Neuromuscular System. In Harding R. Bocking AD. Fetal Growth and Development. Cambridge, United Kingdom: Cambridge University Press. (1st).

United Nations Development Programme [UNDP]. 2018. Human Development Indices and Indicators 2018 Statistical Update. New York. 